\title{
Efektivitas Pelatihan Pijat Bayi terhadap Pengetahuan Pengasuh Bayi di TPA Yaa Bunayya Jember
}

\author{
Ervina Rachmawati', Gamasiano Alfiansyah ${ }^{1}$, Faiqatul Hikmah ${ }^{1}$ \\ Jurusan Kesehatan, Politeknik Negeri Jember, Indonesia ${ }^{1}$ \\ e-mail: ervina_rachmawati@polije.ac.id
}

\begin{abstract}
Baby massage is a method used to improve a baby's fitness through increasing body weight and developing baby's motor skills. Knowledge about baby massage is still unknown to the public, because the community still entrusts baby massage to dukuns and the lack of public knowledge to do baby massage to health workers. This study aims to improve the knowledge and skills of caregivers of infants and toddlers at TPA Yaa Bunayya Jember. This type of research uses comparative analytics with quasi experimental designs. Retrieving data using pre and post test questionnaires. Data analysis techniques using statistical tests paired T test. The results showed that there was a significant difference between knowledge before and after infant massage training $(p=$ 0.001; $t$ count $=-4.614 ; 95 \% C I=-3,077 \mathrm{~s} / \mathrm{d}-1,089$; mean difference $=-2,083)$. Baby massage training has proven to be effective in increasing the knowledge of baby caregivers in practicing baby massage at TPA Yaa Bunayya Jember.
\end{abstract}

Keywords : infant massage, knowledge, training

\section{Pendahuluan}

Pijat adalah terapi tertua yang dikenal manusia dan merupakan seni perawatan kesehatan sejak berabad-abad silam. Pijat bayi yang pertama kali dialami manusia ialah pada waktu dilahirkan, yaitu pada waktu melalui jalan lahir

Manfaat pijat bayi diantaranya untuk membantu tumbuh kembang fisik (motorik) dan emosi bayi, mempererat hubungan antara ibu dan bayi, meningkatkan jumlah dan sitotoksisitas dari sistem immunitas (sel pembunuh alami), merangsang fungsi pencernaan dan pembuangan, membantu melatih relaksasi, mengurangi depresi dan ketegangan, mengurangi rasa sakit, mengurangi kembung dan kolik (sakit perut), meningkatkan berat badan, meningkatkan konsentrasi bayi dan membuat tidur lelap serta memperbaiki sirkulasi darah dan pernapasan (Putri, 2009; Prasetyono, 2009).

Beberapa penelitian membuktikan bahwa pijat bayi secara signifikan dapat menaikkan berat badan bayi preterm jika dibandingkan dengan kelompok kontrol. Hal tersebut juga dikemukakan oleh Teni dan Mega (2018), serta Dasuki (2010) yang membuktikan bahwa pijat bayi dapat menaikkan berat badan pada bayi. Penelitian yang sama dilakukan oleh Lee (2009) dan Purnamasari (2011) pada bayi 4 bulan menunjukkan hasil kenaikan berat badan bayi yang signifikan. Penelitian yang dilakukan oleh Sari (2014) membuktikan bahwa pijat bayi mempunyai efek terhadap pertumbuhan dan perkembangan bayi.

TPA Yaa Bunayya merupakan tempat penitipan anak, bayi, dan balita di Kabupaten Jember. Berdasarkan studi pendahuluan diperoleh hasil bahwa para pengasuh bayi belum mempunyai pengetahuan yang cukup tentang tata cara memijat bayi. Untuk mendapatkan manfaat yang optimal, pemijatan bayi tidak bisa dilakukan sembarangan, ada cara yang harus diperhatikan, pada bayi usia 0 3 tahun, gerakan yang dilakukan lebih mendekati usapan-usapan halus, tekanan ringan, dan dengan tekanan, disarankan pemijatan dilakukan sekitar 15 menit. Urutan pemijatan bayi dianjurkan dimulai dari kaki, kemudian perut, dada, tangan, muka, dan diakhiri pada bagian punggung.

Pengetahuan tentang pijat bayi ini masih belum diketahui oleh masyarakat, dikarenakan masyarakat masih mempercayakan pijat bayi kepada dukun bayi dan kurangnya pengetahuan masyarakat untuk melakukan pijat bayi kepada tenaga kesehatan. Faktor lain yang menyebabkan masyarakat lebih memilih pijat bayi kepada dukun bayi adalah faktor adat istiadat yang masih di pegang teguh dan berkembang secara turun temurun. Serta, adanya keyakinan bahwa dukun bayi dianggap 
lebih mengerti dan mahir dalam melakukan pijat bayi yang sudah dipraktekkan sejak berabad-abad silam. Hal tersebut karena adanya perasaan takut salah memijat bayinya, badan bayi yang masih lemah serta tidak tahu bagaimana teknik memijat yang benar.

\section{Metode}

Jenis penelitian yang digunakan adalah penelitian analitik komparatif yaitu penelitian dengan menganalisis perbedaan sebelum dan setelah pelatihan pijat bayi. Desain penelitian yang digunakan adalah quasi eksperimental. Tempat dan waktu penelitian dilaksanakan di Jurusan Kesehatan Politeknik Negeri Jember.

\subsection{Metode Pengumpulan Data}

Teknik sampling menggunakan total sampling, yaitu seluruh populasi dijadikan sebagai subjek penelitian. Subjek penelitian yang diambil berjumlah 12 orang pengasuh bayi di TPA Yaa Bunayya Jember. Metode pengumpulan data dilakukan dengan cara mengisi kuesioner pre dan post test. Kuesioner pre test diisi sebelum responden mendapatkan pelatihan tentang pijat bayi, sedangkan kuesioner post test diisi setelah responden mendapatkan pelatihan tentang pijat bayi.

\subsection{Metode Analisis Data}

Analisis data penelitian menggunakan uji statistik Paired-t test.

\section{Hasil Dan Pembahasan}

Penelitian ini dilakukan pada pengasuh bayi di TPA Yaa Bunayya Jember sebanyak 12 orang. Adapun variabel yang diteliti adalah pengetahuan dan pelatihan pijat bayi. Tabel 1 menyajikan pengetahuan pengasuh bayi di lokasi penelitian dan tabel 2 menyajikan hasil uji statistiknya.

Tabel 1. Hasil Analisis Univariate pengetahuan pengasuh bayi sebelum dan sesudah pelatihan pijat bayi

\begin{tabular}{lllll}
\hline Karakteristik & $\mathrm{N}$ & Min & Max & Mean \\
\hline Sebelum & 12 & 4 & 8 & 6,42 \\
Sesudah & 12 & 6 & 10 & 8,5 \\
\hline
\end{tabular}

Berdasarkan tabel 1 menunjukkan bahwa nilai rata-rata responden sebelum pelatihan pijat bayi yaitu 6,42 dengan nilai minimal 4 dan nilai maksimal 8 . Nilai rata-rata responden meningkat menjadi 8,5 sesudah dilakukan pelatihan pijat bayi dengan nilai minimal 6 dan nilai maksimal sebesar 10 .

Tabel 2. Hasil Analisis Bivariat uji paired t-test pengetahuan sebelum dan sesudah pelatihan pijat bayi

\begin{tabular}{cccccc}
\hline & MD & \multicolumn{2}{c}{ CI $95 \%$} & t & p value \\
\hline \multicolumn{5}{c}{ low } & Up \\
\hline $\begin{array}{l}\text { Pre- } \\
\text { post }\end{array}$ & $-2,083$ & $-3,077$ & $-1,089$ & $-4,614$ & 0,001 \\
\hline
\end{tabular}

Tabel 2 menunjukkan bahwa ada perbedaan nilai rata-rata (Mean Differences) sebelum dan sesudah pelatihan pijat bayi sebesar $-2,083$. Hasil tersebut diperkuat dengan uji statistik paired $t$-test didapatkan $\mathrm{p}=0,001(<$ $0,05), \mathrm{t}$ hitung $=4,614(>\mathrm{t}$ tabel $=2,201), \mathrm{CI}$ $95 \%=-3,077 \mathrm{~s} / \mathrm{d} \quad-1,089$, maka dapat disimpulkan bahwa $\mathrm{H} 0$ ditolak yang artinya ada perbedaan yang signifikan tentang pengetahuan sebelum dan sesudah pelatihan pijat bayi pada pengasuh bayi di TPA Yaa Bunayya Jember.

Hasil nilai pengetahuan pengasuh bayi sebelum dan sesudah dilakukan pelatihan menunjukkan peningkatan. Nilai rata-rata sebelum pelatihan menunjukkan nilai 6,42 meningkat menjadi 8,5 setelah dilakukan pelatihan. Hal tersebut sejalan dengan nilai mean differences yang menunjukkan angka 2,083 yang artinya rata-rata pengetahuan sebelum pelatihan lebih kecil 2,083 poin dibandingkan dengan rata-rata sesudah dilakukan pelatihan pijat bayi.

Notoatmodjo (2012) menjelaskan bahwa setelah manusia mendapatkan informasi atau pelatihan maka akan diolah lebih lanjut dengan memikirkan, mengolah, mempertanyakan, menggolongkan, dan merefleksikan. Pengetahuan pengasuh yang mengalami peningkatan setelah dilakukan pelatihan pijat bayi dapat direfleksikan dengan sikap yang mendukung pijat bayi dan praktik pijat bayi.

Hasil uji statistik paired t-test didapatkan $\mathrm{p}=0,001(<0,05), \mathrm{t}$ hitung $=4,614(>$ $\mathrm{t}$ tabel $=2,201)$, CI $95 \%=-3,077 \mathrm{~s} / \mathrm{d}-1,089$, maka dapat disimpulkan bahwa ada perbedaan yang signifikan tentang pengetahuan sebelum dan sesudah pelatihan pijat bayi pada pengasuh bayi di TPA Yaa Bunayya Jember. Hal ini menunjukkan bahwa pelatihan pijat bayi memiliki dampak yang efektif terhadap pengetahuan pengasuh bayi di TPA Yaa Bunayya Jember. 
Hal ini sesuai dengan hasil penelitian Baroo'ah (2015) tentang pengaruh pendidikan kesehatan tentang pijat bayi terhadap perilaku ibu dalam memijat bayi. Penelitian ini menunjukkan bahwa terdapat perbedaan perilaku ibu dalam melakukan pijat bayi sebelum dan sesudah diberikan pendidikan kesehatan. Hasil penelitian sebelumnya menyatakan bahwa pelatihan pijat bayi efektif untuk meningkatkan sikap ibu tentang pijat bayi.

Pengetahuan ibu tentang pijat bayi meliputi tentang pengertian pijat bayi, manfaat pemijatan, waktu yang tepat untuk pemijatan, tempat yang nyaman untiuk pemijatan dan Teknik pijat bayi. Adanya pemberian pelatihan dan informasi tentang pijat bayi dapat meningkatkan pengetahuan pengasuh tentang pijat bayi. Hal ini dapat menentukan sikap pengasuh dalam melakukan perilaku pijat bayi terhadap bayi yang diasuhnya.

Hasil penelitian ini diperkuat oleh penelitian yang dilakukan Dewi (2012) yang menunjukkan bahwa ada hubungan antara pengetahuan dengan sikap ibu tentang pijat bayi $(p$-value $=0,041)$.

\section{Simpulan Dan Saran 4.1 Simpulan}

Pelatihan pijat bayi terbukti efektif untuk meningkatkan pengetahuan pengasuh bayi dalam melakukan praktik pijat bayi di TPA Yaa Bunayya Jember, yang dibuktikan dengan peningkatan nilai rata-rata sebelum dan sesudah pelatihan sebesar 2,083.

\subsection{Saran}

Untuk peningkatan kesehatan dan tumbuh kembang bayi, diharapkan TPA Yaa Bunayya bekerjasama dengan Puskesmas sehingga dapat melakukan pelatihan tentang pijat bayi kepada orang tua bayi maupun pengasuh bayi.

\section{Ucapan Terima Kasih}

Ucapan terimakasih peneliti sampaikan kepada Politeknik Negeri Jember selaku pendukung dana melalui dana Bantuan Operasional Perguruan Tinggi Negeri (BOPTN)

\section{Daftar Pustaka}

Baroo'ah. (2015). Pengaruh Pendidikan Kesehatan Tentang Pijat Bayi Terhadap Perilaku Ibu Dalam Memijat Bayi Secara Mandiri Di Keluran Girimargo Sragen. Skripsi Sarjana Keperawatan. Universitas Muhamadiyah Surakarta. Surakarta.

Dasuki. (2010). Pengaruh Pemijatan terhadap Kenaikan Berat Badan dan Lama Tidur Bayi Usia 1 sampai 3 Bulan. Jurnal Penelitian Kesehatan Suara For Ikes Vol II.

Dewi, A.R. (2012). Hubungan antara Pengetahuan dengan Sikap Ibu tentang Pijat Bayi di Kelurahan Wadung Getas Kecamatan Wonosari Klaten. Surakarta : Fakultas Ilmu Kesehatan. Universitas Muhammadiyah Surakarta.

Lee, H.K. (2009). The Effects of Infant Massage on Weight, Height and MotherInfant Interaction. Journal of Korean Academy of Nursing.

Notoatmodjo, S. (2012). Promosi Kesehatan dan Ilmu Perilaku. Jakarta : Rineka Cipta.

Nurlatifah, T. dan Mega. (2018). Efektivitas Pijat Bayi terhadap Peningkatan Berat Badan Bayi. Jurnal Bidan "Midwife Journal" Volume 4 No. 02.

Prasetyono. (2009). Teknik-Teknik Tepat Memijat Bayi Sendiri Panduan Lengkap dan Uraian Kemanfaatannya. Yogyakarta : Bina Pustaka.

Purnamasari, D. (2011). Panduan Pijat Praktis Balita Anda agar Cerdas dan Sehat. Yogyakarta : Pustaka Solomon.

Putri, A. (2009). Pijat dan Senam untuk Bayi dan Balita Panduan Praktis Memijat Bayi dan Balita. Yogyakarta : Brilliant Offset.

Roesli, U. (2009). Pedoman Pijat Bayi Prematur \& Bayi Usia 0-3 bulan. Jakarta: PT. Trubus Agriwidya.

Sari, P.E.K. (2014). Efektivitas Pijat Bayi terhadap Pertumbuhan dan Perkembangan Bayi Usia 6 Bulan di Kelurahan Bintaro Jakarta. Skripsi. 
ISSN : 2354-5852

e-ISSN : 2579-5783

Jakarta : Universitas Islam Negeri Syarif Hidayatullah.

4 | Jurnal Kesehatan Vol. 7. No. 1. April 2019 